\title{
INTERNATIONAL INSTRUMENTS AND ARRANGEMENTS IN THE SUB-ANTARCTIC
}

\author{
by Andrew Jackson
}

(with one text-figure and one table)

\begin{abstract}
Jackson, A. 2007 (23:xi): International instruments and arrangements in the sub-Antarctic. Papers and Proceedings of the Royal Society' of Tasmania 141(1): 141-148. https://doi.org/10.26749/rstpp.141.1.141 ISSN 0080-4703. Australian Antarctic Division, Channel Highway, Kingston, Tasmania 7050, Australia.
\end{abstract}

\begin{abstract}
This paper places the sub-Antarctic region in its international context by contrasting the sub-Antarctic's geographical qualities with the region's international legal and political characteristics. It shows that the international aspects of the legal regime applying in the sub-Antarctic are less developed than in the Antarctic. An overview is provided of some of the most relevant international instruments and arrangements that apply. This includes an analysis of some of the matters that are regulated and some that are not regulated. It is concluded that there is no requirement for a dedicated international regime in the sub-Antarctic, but there is substantial scope for further internationally cooperative arrangements to address the immediate issues facing the sub-Antarctic region.
\end{abstract}

Key Words: sub-Antarctic islands, international law, maritime law, environmental law, Antarctica, Southern Ocean.

\section{INTRODUCTION}

\section{Is the sub-Antarctic special?}

Most of the sub-Antarctic region is characterised by bleak expanses of ocean with few landfalls. The vast majority of the area embraced by the sub-Antarctic, where ocean encircles the globe, is essentially devoid of continental intrusions. The main exception is southern South America which, at its southernmost extremity, is in many ways sub-Antarctic with respect to climate, biogeography and the cultural aspects of small and remote communities.

It is therefore useful to look at whether the dominance of the ocean and the relative lack of inhabited land in the sub-Antarctic give rise to special international instruments and arrangements. From a legal and political perspective, the sub-Antarctic region is quite unlike the area south of $60^{\circ} \mathrm{S}$. Most Antarctic policy advisers look beyond the sub-Antarctic to Antarctica, where there are more challenging jurisdictional issues and geopolitical forces calling for attention. The absence of universal recognition of territorial claims in that area underpinned the negotiation of the Antarctic Treaty (1961). The 1959 Treaty set aside sovereignty arguments and allowed international cooperation to proceed on a continental and, some would say, global scale. This was remarkable and also critical to providing the governance framework for essentially all human activities — a special solution for a special place.

The Treaty itself spawned what is now known as the Antarctic Treaty system, which has developed into a wide-ranging and largely integrated regime for regulating activities south of $60^{\circ} \mathrm{S}$ and, equally important, for providing forums for consultation between actors in the Antarctic. This has had the effect of diminishing the effect of other international instruments in the Antarctic. The Treaty "system" is usually described as embracing the numerous international agreements, instruments and institutional arrangements that flowed from the Treaty.

By contrast, north of $60^{\circ} \mathrm{S}$, we have what is an equally special place - but we do not have an equally special solution to its governance needs. In the sub-Antarctic there is a much broader opportunity for a wide range of other international and domestic regimes to take full effect. A coherent single regime, as applies in the Antarctic, is not mirrored in the sub-Antarctic.

While different from the Antarctic, the sub-Antarctic region is also clearly different from the temperate areas further north. For a start, it is maritime, remote and barely inhabited (although it would be wrong to assume that any of it is uninhabitable). Sovereignty issues take a lower profile. The sub-Antarctic is, in terms of international law, not part of the Antarctic regime, or subject to an international regime of its own. This comes in part from its remoteness and, to a large degree, the absence of permanent human population. International instruments are, however, increasingly being applied in the region.

Unlike more temperate areas, the sub-Antarctic is generally not industrialised, although historically this was not the case. Past industrial occupation of several sub-Antarctic islands for sealing for skins and oil no longer applies. In some case the sites and relics associated with such use are recognised as having heritage values. Fishing is a current industrial use, and tourism is an intermittent commercial use of the region.

While much of the interest in the sub-Antarctic region focuses on the islands, most of the region is comprised of ocean. International maritime law therefore takes on particular importance, currently with particular respect to marine living resources, and other aspects of international law may have increasing application with respect to potential future interests.

International environmental instruments are especially relevant to the islands. The now well-recognised natural values of the sub-Antarctic have precipitated a growing interest in the application of international environmental management and protection regimes. That said, the subAntarctic has not had detailed assessment of the need for integration of the international regimes that apply.

So the sub-Antarctic is special in terms of the application of international instruments. Much of the uniqueness is explained by the remote maritime and island nature of the region and, arguably, there is potential for extending the application of international environmental and other instruments. There is also scope for harmonising the application of instruments in domestic law. 
Other papers in this volume have sought to define the sub-Antarctic. For a definition of the sub-Antarctic useful to understanding the region's international arrangements, a map of the region would blank out the Antarctic Treaty area and the major inhabited land masses of Australia, New Zealand, South America and South Africa. The sub-Antarctic would be neatly cut off at $60^{\circ} \mathrm{S}$. However, to the north there is no legal or geopolitical boundary and the sub-Antarctic map-maker might resort to an oceanic boundary such as the Subtropical Front which is the northernmost extent of sub-Antarctic waters (Orsi et al. 1995). However, to do this would exclude the Chatham Islands, Tristan da Cunha, îles Amsterdam and Îles St Paul which lie just north of the Front. It is therefore expedient to draw the line at around $30^{\circ} \mathrm{S}$. Using these boundaries the map becomes a sub-Antarctic "doughnut" comprised of a vast marine area with tiny flecks of land which are the sub-Antarctic islands (fig. 1).

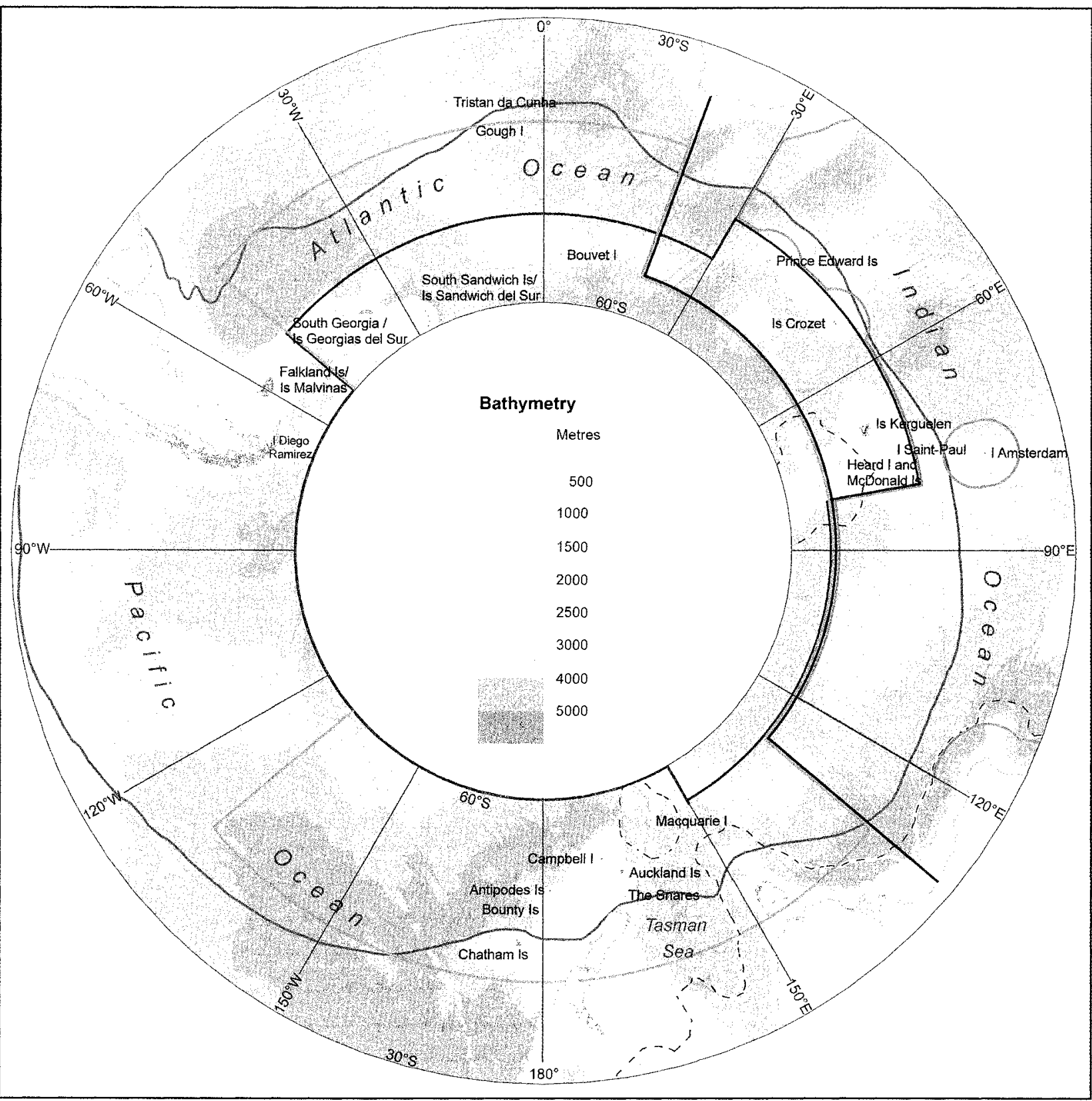

\section{Sub-Antarctic Region}

\section{Jurisdictional and Administrative Boundaries}

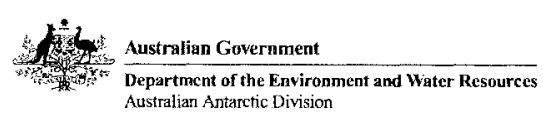

Polar Stereographic projection.

Produced by the Australian Antarctic Data Centre, Aug 2007

Map available at : $h t t p: / / a a d c-m a p s . a a d$ gov.au/aadc/mapcat/ Map Catalogue No. 13415
CCAMLR Area boundary

Continental shelf limit of Australian territory Outer limit of Australian Exclusive Economic Zone

Subtropical Front

Southern Indian Ocean Fisheries Agreement boundary

Southem Ocean Whale Sanctuary boundary Indian Ocean Whale Sanctuary boundary

FIG. 1 - Sub-Antarctic region: jurisdictional and administrative boundaries. 
Table 1 indicates the countries which can be regarded as the sub-Antarctic states. These are the states exercising or asserting jurisdiction over lands in the sub-Antarctic region. These states are generally party to the international instruments and arrangements applying in the region.

\section{MARITIME AND FISHERIES INSTRUMENTS THAT APPLY IN THE SUB-ANTARCTIC}

\section{Law of the Sea Convention}

The Law of the Sea Convention (United Nations Convention on the Law of the Sea, 1982) seeks to provide governance of the world's oceans. It promotes peaceful use of the oceans and equitable use of resources. All of the sub-Antarctic states are party to UNCLOS.

Among other things, the Convention provides for the assertion of maritime zones subject to national jurisdiction. A line extending from the shores of a sub-Antarctic island into the great Southern Ocean would cross a number of UNCLOS zones.

TABLE 1

\section{The sub-Antarctic states}

\begin{tabular}{|c|c|}
\hline State & Interes $\tau^{1}$ \\
\hline Argentina & $\begin{array}{l}\text { Georgias del Sur } \\
\text { Islas Malvinas } \\
\text { Islas Sandwich del Sur } \\
\text { (Southern Argentina and its islands also extend } \\
\text { south of the Subtropical Front) }\end{array}$ \\
\hline Australia & $\begin{array}{l}\text { Heard Island and McDonald Islands } \\
\text { Macquarie Island }\end{array}$ \\
\hline Chile & $\begin{array}{l}\text { Islas Diego Ramirez } \\
\text { (Southern Chile and its islands also extend } \\
\text { south of the Subtropical Front) }\end{array}$ \\
\hline France $^{2}$ & $\begin{array}{l}\text { Île Amsterdam } \\
\text { Île Kerguelen } \\
\text { Île Saint-Paul } \\
\text { Îles Crozet }\end{array}$ \\
\hline New Zealand & $\begin{array}{l}\text { Antipodes Islands } \\
\text { Auckland Island } \\
\text { Balleny Islands } \\
\text { Bounty Islands } \\
\text { Campbell Island } \\
\text { Chatham Islands } \\
\text { The Snares }\end{array}$ \\
\hline Norway $^{2}$ & Bouvetøya \\
\hline South Africa & $\begin{array}{l}\text { Marion Island } \\
\text { Prince Edward Island }\end{array}$ \\
\hline $\begin{array}{l}\text { United King- } \\
\text { dom }{ }^{2}\end{array}$ & $\begin{array}{l}\text { Falkland Islands } \\
\text { Gough Island } \\
\text { South Georgia } \\
\text { South Sandwich Islands } \\
\text { Tristan da Cunha }\end{array}$ \\
\hline
\end{tabular}

1 This list is not intended to be exhaustive, nor is it intended to reflect on unresolved questions of sovereignty. It excludes islands within the Antarctic Treaty area.

${ }^{2}$ A Northern Hemisphere state.
It would first cross the Territorial Sea. The Territorial Sea is established by Article 2 of UNCLOS and gives the coastal state sovereignty to the waters, seabed and airspace generally to 12 nautical miles. A Territorial Sea is asserted by all sub-Antarctic coastal states. At 24 nautical miles there is the limit of the Contiguous Zone (Article 33 of UNCLOS) within which a coastal state may prevent infringement of certain aspects of its domestic law.

The Exclusive Economic Zone (EEZ) is crossed next. The EEZ is established by Part $\mathrm{V}$ of UNCLOS. Among other things, the EEZ provides rights to the living and non-living resources of both the water column and the seabed. It generally applies to a limit of 200 nautical miles, but it is subject to delimitation with other coastal states (and there are several examples of delimitation agreements in the sub-Antarctic region - for example, the agreement between Australia and France with respect to the otherwise overlapping EEZs generated by Australia's Territory of Heard Island and McDonald Islands and the France's Îles Kerguelen). EEZs are asserted in the sub-Antarctic region by all of the coastal states in the sub-Antarctic.

Even further from the coast comes the area of extended continental shelf. This zone is established by UNCLOS Article 76 which, in essence, provides for exclusive access to the resources of the seabed (as opposed to the water above) in the area beyond the EEZ. This zone can only exist if a physical continental shelf can be shown to exist and to extend beyond the EEZ. This needs to be established by submitting data (such as bathymetric and seismic data), to the Commission on the Limits of the Continental Shelf which is established under UNCLOS to assess and provide recommendations on the shelf areas identified by coastal states.

While sub-Antarctic states have generally asserted territorial seas and EEZs, matters are still evolving with respect to the continental shelf beyond the EEZ. So far, submissions of data to define extended continental shelves in the sub-Antarctic region have been lodged by Australia (in November 2004) and New Zealand (in April 2006) but recommendations on these submissions are yet to be made by the Commission on the Limits of the Continental Shelf. Whether or not extended shelf claims will be made in respect of other sub-Antarctic islands remains to be seen as the provisions of Article 76 are only just starting to be implemented by states parties to UNCLOS.

Beyond the extended continental shelf is the region described by UNLCOS as "the Area", which is subject to special rules that reflect the principle of the common heritage of mankind, and is controlled by the International Seabed Authority. The boundaries of the Area have not yet been defined, but the sub-Antarctic region consists of vast regions of the Area.

Both the extended continental shelf and the Area are issues which over the next few years may result in some new lines on the sub-Antarctic map.

It should also be noted that these maritime boundaries may change from time to time. In geological time scales, many sub-Antarctic islands are quite young and land-masses are continuing to emerge - in some cases quite rapidly where there is active volcanism. It is interesting to speculate on the new claims that might be asserted if new islands emerge, or indeed lands that might be lost if baselines retreat because of sea level rise - but these are matters for future generations. 


\section{CCAMLR}

CCAMLR (Convention on the Conservation of Antarctic Marine Living Resources 1980) provides for the conservation of living marine resources of the Antarctic. Article II paragraph 2 of the Convention defines conservation as including rational use. The Convention's area of application roughly approximates to the area south of the Antarctic Polar Front and therefore much of it extends north of the Antarctic Treaty area, well into the sub-Antarctic. All of the sub-Antarctic states are party to CCAMLR.

Many sub-Antarctic islands are in the CCAMLR area - but not all. For example, in the immediate region of Australia, Macquarie Island and New Zealand's Auckland Island and Campbell Island are outside the CCAMLR area, albeit they support ecosystems and fisheries with many similarities to islands within the CCAMLR area

The CCAMLR regime includes the so-called "Chairman's Statement" (CCAMLR 1980, pp. 23-24) which essentially allows states whose island territories are within the CCAMLR area to exercise their domestic jurisdiction in accordance with CCAMLR Conservation Measures and to apply more stringent national measures in their waters if they wish. Furthermore, it allows for these coastal states to take enforcement action as a sovereign act and it allows a state to opt out of a Conservation Measure. This provision has been used from time to time in limited circumstances.

\section{Other fisheries regimes}

Other relevant fisheries regimes and agreements include the Whaling Convention (International Convention on the Regulation of Whaling 1946) which sets out to "provide for the proper conservation of whale stocks and thus make possible the orderly development of the whaling industry". There are well-known debates within the International Whaling Commission with respect to how the Commission goes about meeting the Convention's objectives and the various aspirations of the parties. The Whaling Convention is relevant as sanctuaries established under the convention embrace the waters south of $40^{\circ} \mathrm{S}$. The Indian Ocean Sanctuary and the Southern Ocean Whale Sanctuary take in the waters of several sub-Antarctic islands.

CCSBT (the Convention for the Conservation of Southern Bluefin Tuna 1993) provides for the conservation and optimum use of this highly prized pelagic species. The subAntarctic states that are party to CCSBT are Australia and New Zealand. Other parties to the Convention are Japan, the Republic of Korea and the Fishing Entity of Taiwan and thus they have an interest in the sub-Antarctic region because the convention itself specifies no geographical limits, the range of the Southern Bluefin Tuna range extends into the region, and the fish are caught there.

The Australia/France maritime cooperation treaty (Treaty Between the Government of Australia and the Government of the French Republic on Cooperation in the Maritime Areas Adjacent to the French Southern and Antarctic Territories (TAAF), Heard Island and the McDonald Islands 2003) provides for cooperation in the maritime areas adjacent to France's Îles Kerguelen and Australia's Territory of Heard Island and McDonald Islands. The Treaty sets out to facilitate cooperation in responding to illegal, unregulated and unreported fishing.
The Southern Indian Ocean Fisheries Agreement (2006) is expected to enter into force in the near future. The agreement includes the waters around Île Amsterdam and Île SaintPaul. The agreement provides for cooperation between states, organisations and fishing entities having an interest in the fishery resources of the Southern Indian Ocean to ensure compatible conservation and management measures.

\section{INTERNATIONAL ENVIRONMENTAL INSTRUMENTS}

Some environmental instruments apply, or are capable of applying, to some or all of the sub-Antarctic islands. Most of these instruments involve matters or actions that cross jurisdictional boundaries.

\section{World Heritage Convention}

The World Heritage Convention (Convention for the Protection of the World Cultural and Natural Heritage 1972) sets out to protect sites of outstanding and universal value. All states with sub-Antarctic islands are party to the Convention. The first listing of sub-Antarctic properties was in 1997 with the inscription of Australia's Macquarie Island (listed for its value in representing significant ongoing geological processes in the development of landforms and for its aesthetic values) and the Territory of Heard Island and McDonald islands (listed for geophysical values, as well as for the values in demonstrating ongoing ecological and biological processes). The NewZealand sub-Antarcticislands followed in 1998.

World Heritage nominations have been made for Marion Island and Prince Edward Island as a single site and it is expected that a decision will be made to inscribe the property on the World Heritage list. Nominations for other sub-Antarctic properties are not anticipated in the immediate future.

\section{Bonn Convention}

The Bonn Convention (Convention on Migratory Species 1979) aims to conserve terrestrial, marine and avian species throughout their range. All of the sub-Antarctic states are party to the Convention. The Convention is relevant to all the sub-Antarctic islands because of the number of migratory species involved, especially migratory birds that occur in the region.

\section{ACAP}

ACAP (Agreement on the Conservation of Albatrosses and Petrels 2001) was developed under the auspices of the Bonn Convention and entered into force in 2004 . Its objective is to conserve albatrosses and petrels by coordinating activities to mitigate known threats. The parties to ACAP with subAntarctic interests include Argentina, Australia, Chile, France, New Zealand, Norway, South Africa and the United Kingdom. ACAP is relevant to all the sub-Antarctic islands because of the ubiquitous presence of these iconic bird species, many of which are threatened by fishing practices in the Southern Ocean. 


\section{Ramsar Convention}

The Ramsar Convention (Convention on Wetlands of International Importance Especially as Waterfowl Habitat 1971) provides for the conservation and wise use of wetlands through national and regional actions and international cooperation. It has a special interest in waterbirds. All of the states with sub-Antarctic islands are party to the convention. Although there are numerous sub-Antarctic sites that prima facie qualify as important wetlands, including for waterbirds, no sub-Antarctic properties have been listed. Nevertheless, nominations are expected.

\section{CITES}

CITES (Convention on the International Trade of Endangered Species of Wild Fauna and Flora 1973) seeks to ensure that trade does not threaten the survival of species. All sub-Antarctic states are party to the Convention. Various species of marine mammals present in the sub-Antarctic region are listed in Annex II of CITES, including several species of seals and dolphins.

\section{MARPOL}

MARPOL 73/78, which comprised the convention and its subsequent protocol (International Convention for the Prevention of Pollution from Ships 1973 as Modified by the Protocol of 1978 Relating Thereto 1978) addresses marine pollution throughout the world's oceans and entered into force on 2 October 1983. All sub-Antarctic states are party to both instruments. Subsequently, numerous subsidiary annexes and amendments have been added to this now well-developed regime, but there is not enough space here to provide a detailed survey of which states are parties to each of them. One of the affiliated conventions deals with ballast water, an issue which is addressed below.

\section{Convention on Biological Diversity}

The Biodiversity Convention (Convention on Biological Diversity 1992) seeks to conserve biological diversity and regulate sustainable use while allowing equitable sharing of benefits. All sub-Antarctic states are party to the Convention. The Convention allows the establishment of protected areas where special measures can be taken to conserve biological diversity. In Australia's case, the Heard Island and McDonald Island Marine Reserve assists Australia meets its obligations under the Convention.

\section{OTHER INTERNATIONAL ARRANGEMENTS}

Other arrangements that are international in character but do not involve legal instruments also apply in the subAntarctic region.

\section{IUCN}

IUCN, or World Conservation Union as it is also known (International Union for the Conservation of Nature and
Natural Resources 2007), was established in 1948 and acts as a network of states, inter-governmental and nongovernment organisations to encourage conservation and sustainable use of natural resources. IUCN's particular relevance in the sub-Antarctic region is with respect to protected area management. This is consistent with its objective of promoting a representative network of terrestrial and marine protected areas. IUCN provides advice on world heritage values, and it established the now widely recognised categories of protected areas. IUCN is also interested in high seas management, especially fisheries issues such as bottom trawling.

IUCN maintains the Red List or the world's vulnerable, threatened and endangered species — these include subAntarctic species such as albatrosses threatened by long-line fishing.

\section{UNESCO}

UNESCO is a long-established agency of the United Nations. UNESCO's inter-disciplinary Man and Biosphere Program provides for a unique category of protected area (United Nations Educational, Scientific and Cultural Organization 2007). Biosphere Reserves are designated as important areas for conserving biological diversity and furthering scientific knowledge. Macquarie Island was listed as a Biosphere Reserve in 1977 and, to this point, remains the first and only true sub-Antarctic site to be so designated (although there is a Biosphere Reserve at Cape Horn, which is at a comparable latitude). As UNESCO Biosphere Reserves are primarily directed towards areas where conservation objectives need to be balanced against sustainable development interests, it is unlikely that in the near future there will be further designation of Biosphere Reserves in the remote and isolated sub-Antarctic region where sustainable development issues are not a current concern.

\section{SCAR}

SCAR is an inter-disciplinary committee of the International Council of Science (Scientific Committee on Antarctic Research 2007). Its role is to coordinate high-quality international research in the Antarctic region. SCAR, while not formally constituted as such, is often regarded as a de facto component of the Antarctic Treaty system even though its mandate goes well beyond the Antarctic Treaty area. SCAR has a broad interest and thus, while having a focus on the Antarctic Treaty area, takes a keen interest in Southern Ocean research more generally and science that is conducted on the sub-Antarctic islands. Some SCAR-endorsed science programs conduct research across the Antarctic and sub-Antarctic regions. All of the sub-Antarctic states are members of SCAR and contribute to the research programs that it endorses.

\section{IPY}

An international polar year (IPY) has previously been celebrated in 1882/83, 1932/33, and 1957/58. The 4th IPY (International Polar Year 2007) covers research in both the Arctic and the Antarctic. It also includes research in the sub-Antarctic region. While limited to a two-year period, 
IPY was planned on the basis of leaving a legacy of enhanced international scientific collaboration.

\section{Bilateral cooperation}

As examples of bilateral cooperation arrangements, JAMBA (Agreement between the Government of Australia and the Government of Japan for the Protection of Migratory Birds in Danger of Extinction and their Environment 1974) and CAMBA (Agreement between the Government of Australia and the Government of the People's Republic of China for the Protection of Migratory Birds and their Environment 1986) are agreements respectively between Australia and Japan and China on the protection of migratory birds. These two agreements, which are limited to those specific bilateral relationships, provide for cooperation on the management and protection of migratory birds. Heard Island includes species which are subject to the agreements with Japan and China. There may emerge other bilateral cooperation agreements between sub-Antarctic states which have implications for the management of the sub-Antarctic islands.

\section{SUB-ANTARCTIC ACTIVITIES THAT ARE NOT INTERNATIONALLY REGULATED}

Many activities in the sub-Antarctic are not regulated by international instruments. Tourist interest in the sub-Antarctic region continues to grow. Sub-Antarctic islands currently have their own regimes for controlling tourist access and managing their activities on the ground. There may be merit in developing consistent tourism management measures for the sub-Antarctic islands and, given that sub-Antarctic sites are often visited in conjunction with visits to Antarctica, there is an opportunity to harmonise them with the emerging regulations for the Antarctic region. This could include guidelines on visitor behaviour near wildlife or sensitive vegetation, safety standards, self-sufficiency and insurance.

Quarantine matters are not internationally regulated for the sub-Antarctic islands. Each sub-Antarctic state implements its own domestic requirements either through legislation, permit conditions, training or other administrative mechanisms and, as Potter (2007) points out, arrangements can differ even for sub-Antarctic islands belonging to the same country. The importance of addressing the quarantine issue is underlined by the known sensitivity of some sub-Antarctic sites to new introductions as well as, at some sites, by the paucity of scientific assessments of the natural reference state.

MARPOL already addresses waste disposal and pollution from ships. However, there may be scope for specific measures to be internationally agreed for sub-Antarctic islands and adjacent waters where there are particular vulnerabilities in the marine and terrestrial ecosystems.

The Ballast Water Convention (International Convention for the Control and Management of Ships' Ballast Water and Sediments 2004) has not yet entered into force. This convention is part of the MARPOL family. To this point there are only six parties, covering less than $1 \%$ of ship tonnage globally. The convention requires that, where possible, ballast water should be exchanged more than 200 nautical miles from the nearest land and in water over 200 metres deep. Otherwise it should be done more than 50 nautical miles from land. Where these circumstances cannot be met then areas can be designated for ballast water discharge. A Party or Parties may impose additional measures to prevent or reduce the transfer of harmful aquatic organisms.

The 2006 Antarctic Treaty meeting adopted a resolution and guidelines on the management of ballast water in the Antarctic (Antarctic Treaty 2006). To further reduce the risk of introducing invasive marine species in the subAntarctic, there is merit in special management measures for the sub-Antarctic islands to achieve consistency with the Antarctic regime, and consistency between sub-Antarctic islands. It is arguable that the sub-Antarctic islands are at least as vulnerable as Antarctic waters to the introduction of marine pests, especially so since every ship travelling to the Antarctic has to pass through the sub-Antarctic.

\section{POSSIBLE FUTURE INTERNATIONAL ARRANGEMENTS}

There is potential for further international arrangements, but this paper does not argue the case for new legal instruments unique to the sub-Antarctic - they are not necessary. However, there is a strong argument for developing cooperative approaches to addressing the region's management challenges.

As noted above, the Antarctic Treaty provides a robust, stable and effective consultative mechanism to develop management approaches in Antarctica. However, there is no comparable ongoing international mechanism within which to exchange information about the sub-Antarctic region and to develop consistent procedures. Apart from the 2006 forum in Tasmania, there have been previous workshops under the auspices of SCAR and IUCN, but these have been intermittent. Considerable benefits could be achieved by putting in place a regular, structured forum or network for the exchange of views about sub-Antarctic issues, including environmental management issues.

Such a forum or network would be based on the common values of the sub-Antarctic region - the oceanic marine environment; the values of the island ecosystems; the scientific opportunities; the cultural values; and the outstanding natural values.

\section{POSSIBLE NEW INITIATIVES}

A regular and structured forum or network would also facilitate the exchange of ideas and expertise on management of the sub-Antarctic region, especially the islands which are already facing significant environmental issues.

Matters that could usefully be explored and have agreed procedures developed include:

- management of tourism, with a particular emphasis on developing consistent rules of behaviour to apply to visitors at all islands

- consistent quarantine procedures: for example, there would be value in shared development of mechanisms for preventing or responding to introduced species (this could be particularly useful at places like Heard Island, which is one of the places with the lowest number of non-indigenous species, but whose closest neighbour is Îles Kerguelen, which has one of the highest numbers of alien introductions)

- regional responses to fuel spills, including measures for 
cooperative responses and exchange of information and experience with response

- special arrangements that may need to be made with respect to safety of shipping in poorly chartered waters, or safety of distant water sailors and fishers who may operate in the vicinity of sub-Antarctic islands

- a case could possibly be made for declaring the subAntarctic islands, as a group, as MARPOL special areas (e.g., for waste disposal or ballast water handling)

- a mechanism for the timely exchange of scientific data, including a capacity to inform SCAR and national program scientists what research needs to be done to inform management decisions

- exchange of environmental management information: this could lead, for example, to a state of the environment reporting process for the sub-Antarctic

- coordination of scientific research in the sub-Antarctic region after the conclusion of IPY, in consultation with SCAR and focused on sub-Antarctic research priorities

- monitoring, particularly on the unoccupied islands where there is scant available information, but also monitoring which will inform management of the sub-Antarctic islands individually and as a group

- exchange of information on opportunities for logistic cooperation: this could have the effect of extending to the sub-Antarctic region the kind of cooperation achieved under COMNAP (Council of Managers of National Antarctic Programs 2007) in Antarctica.

A regular forum or network would also provide a mechanism to develop proposals that can be taken into other international forums and instruments, or to inform domestic policy making and regulatory mechanisms in a way which is consistent across the relevant jurisdictions. A forum could also be used to provide a context for making the case for funding programs in the sub-Antarctic islands which often have to compete with funding for higher profile activities in the Antarctic.

It is often observed that the sub-Antarctic islands are among the areas more susceptible to climate change. For example, the glaciers of Heard Island (which is close to the Antarctic Polar Front) have been observed to be particularly sensitive to warming. An international network could help prepare common responses to environmental changes that may occur - for example, this could include monitoring in areas which are particularly sensitive to climate change and the development of procedures that assist in dealing with the environmental consequences of change.

A sub-Antarctic forum or network could be supported by a website devoted to matters of common interest across the sub-Antarctic region, and funded by modest national contributions.

\section{CONCLUSIONS}

Unlike the Antarctic, the sub-Antarctic region does not require a special international regime - and, in all likelihood, it could be very difficult to negotiate one. The jurisdictional situation allows effective use of domestic legal regimes and there is good evidence that domestic regimes have considerable rigour.

However, and possibly as a result, there is inconsistent use of legal instruments in the sub-Antarctic. Nevertheless, there is increasing application of the various international instruments, most particularly in the area of environmental management. While the application of the instruments continues to evolve, these developments are not happening in a coherent or integrated way. This should not be seen as a negative. But it does point to an opportunity for greater international collaboration which may encourage consistency between the states with sub-Antarctic interests. In particular, there may be value in more regular forums for an exchange of views on topical environmental and management issues. This can be complemented by developing a network of managers, scientists and policy makers to advance the issues that are unique to the sub-Antarctic region.

\section{ACKNOWLEDGEMENTS}

This paper was prepared with assistance from Tom Maggs and Ewan Mclvor of the Australian Antarctic Division. The map was prepared by David Smith and Angela Bender. The views expressed in this paper are the author's own and do not necessarily represent the views of the Australian Government.

\section{REFERENCES}

Agreement between the Government of Australia and the Government of Japan for the Protection of Migratory Birds in Danger of Extinction and their Environment 1974: Tokyo, 6 Feb 1974. www.austlii.edu.au//cgi-bin/ disp.pl/au/other/dfat/treaties/1981/6. Accessed 2 April 2007.

Agreement between the Government of Australia and the Government of the People's Republic of China for the Protection of Migratory Birds and their Environment 1986: Canberra, 20 Oct 1986. www.austlii.edu.au// cgi-bin/disp.pl/au/other/dfat/treaties/1988/2. Accessed 2 April 2007.

Agreement on the Conservation of Albatrosses and Petrels 2001: Canberra 19 June 2001. www.acap.aq/acap/ text_of_the_agreement. Accessed 2 April 2007.

Antarctic Treaty 1961: Washington, 1 December 1961. www.ats. aq/uploaded/treaty_original.pdf. Accessed 2 April 2007.

Antarctic Treaty 2006. Final Report of the Twenty-ninth Consultative Meeting. Secretariat of the Antarctic Treaty, Buenos Aires: 247-250.

Convention for the Conservation of Southern Bluefin Tuna 1993: Canberra, 10 May 1993. www.ccsbt.org/docs/ pdf/about_the_commission/convention.pdf. Accessed 2 April 2007.

Convention for the Protection of the World Cultural and Natural Heritage 1972: Paris, 23 November 1972. whc.unesco. org/en/conventiontext. Accessed 2 April 2007.

Convention on Biological Diversity 1992: Rio de Janeiro, 5 June 1992. www.biodiv.org/convention/convention.shtml. Accessed 26 June 2007.

Convention on the Conservation of Antarctic Marine Living Resources 1980: Canberra, 20 May 1980. www.ccamlr. $\mathrm{org} / \mathrm{pu} / \mathrm{e} / \mathrm{e} \_$pubs/bd/ptl.pdf. Accessed 2 April 2007.

Convention on the Conservation of Migratory Species of Wild Animals 1979: Bonn, 23 June 1979. www.cms. int/documents/convtxt/cms_convtxt. Accessed 2 April 2007.

Convention on the International Trade of Endangered Species of Wild Fauna and Flora 1973: Washington, 3 March 1973. www.cites.org/eng/disc/text.shtml. Accessed 2 April 2007.

Convention on Wetlands of International Importance Especially as Waterfowl Habitat 1971: Ramsar, 2 Feb 1971. www. ramsar.org/key_conv_e.htm. Accessed 2 April 2007. 
Council of Managers of National Antarctic Programs 2007: www.comnap.aq. Accessed 28 June 2007.

International Convention for the Control and Management of Ships' Ballast Water and Sediments 2004: London, 13 February 2004. http://globallast.imo.org/index. asp? page $=$ mepc.htm\&menu=true. Accessed 2 April 2007.

International Convention for the Prevention of Pollution from Ships (1973) as Modified by the Protocol of Relating Thereto 1978: London, 17 February 1978. www.imo.org/ Conventions/contents.asp?doc_id=678\&topic_id $=258$ ). Accessed 26 June 2007.

International Convention for the Regulation 1946: Washington 2 December 1946. Www.iwcoffice.org/commission/ convention.htm. Accessed 2 April 2007.

International Polar Year 2007: www.ipy.org. Accessed 28 June 2007.

International Union for the Conservation of Nature and Natural Resources 2007: www.iucn.org. Accessed 28 June 2007.

Orsi, A.H., Whitworth III, T. \& Nowlin Jr, W.D. 1995: On the meridional extent and fronts of the Antarctic Circumpolar Current. Deep-Sea Research I 42(5): 641-673.

Potter, S.A. 2007: The quarantine protection of sub-Antarctic Australia: two islands, two regimes. Island Studies Joumal 2(2): (in press).
Scientific Committee on Antarctic Research 2007: www.scar. org. Accessed 28 June 2007.

Southern Indian Ocean Fisheries Agreement 2006: Rome, 7 July 2006. www.fao.org/legal/TREATIES/035t-e.htm. Accessed 2 April 2007.

Treaty Between the Government of Australia and the Government of the French Republic on Cooperation in the Maritime Areas Adjacent to the French Southern and Antarctic Territories (TAAF), Heard Island and the McDonald Islands 2003: Canberra, 24 Nov 2003. www.austlii.edu. au//cgi-bin/disp.pl/au/other/dfat/treaties/2005/6. Accessed 2 April 2007.

United Nations Convention on the Law of the Sea 1982: Montego Bay, 10 December 1982. www.un.org/Depts/ los/convention_agreements/texts/unclos/closindx.htm. Accessed 2 April 2007.

United National Educational Scientific and Cultural Organization 2007: http:/www.unesco.org/mab. Accessed 28 June 2007.

(accepted 30 July 2007) 